\title{
Fluctuation of Indian monsoon during the last glacial period revealed by pollen analysis of Kathmandu Basin sediments, Nepal Himalaya
}

\author{
Rie Fujii†*, Harutaka Sakaił and Norio Miyoshi† \\ † Faculty of Science, Okayama University of Science, Ridaicho 1-1 Okayama, 700-0005, JAPAN \\ ¥Department of Earth Sciences, Kyushu University, Ropponmatsu 4-2-1, Fukuoka, 810-8560, JAPAN \\ *Towhom correspondence should be addressed.E-mail:rfuji@chem.ous.ac.jp, riezof28@yahoo.co.jp
}

Palynological and sedimentorogical studies of a 218-m-long core taken from the Kathmandu Basin by Paleo-Kathmandu Lake Project have revealed continuous record of paleoclimatic changes in the valley during the last $750 \mathrm{ka}$ (Fujii et al. 2004 and Maki et al. 2004). This is the first report on the continuous terrestrial climatic record in South Asia. In this paper, we report millennial-scale climatic changes in the valley from 50 ka to 12 $\mathrm{ka}$, and attempt to compare the result with the glaciation in the Himalaya and the ice cores in both Greeanland and Antarctica.

The Kathmandu basin-fill sediments consist of the late Pliocene to Pleistocene thick fluvio-lacustrine sediments. The 218-m-long core was obtained at Rabibhawan in the western central part of the Kathmand Valley. The core is lithologically divided into three parts (Sakai et al. 2001): 1) $15 \mathrm{~m}$ thick gravelly mud at the basal part (Bagmati Formation), 2) $187 \mathrm{~m}$ thick clayey and muddy sediments in the middle (Kalimati Formation), 3) 9 $\mathrm{m}$ thick sand bed at the top (Patan Formation). On the basis of magnetostratigraphic study and $\mathrm{AMS}^{14} \mathrm{C}$ dating, ages of the core have been estimated to range from ca. 750 to $12 \mathrm{ka}$. We carried out pollen analysis for the samples obtained at $1 \mathrm{~m}$ intervals from the 218-m-long core, in order to clarify the outline of a paleoclimatic changes (Fujii et al. 2004, Maki et al. 2004), and then reconstructed millennial-scale climatic changes from 50 to $12 \mathrm{ka}$ using samples taken at $10 \mathrm{~cm}$ intervals for the top part of the core ( $45 \mathrm{~m}$ in length).

The pollen diagram of 218-m-long core is characterized by predominance of Quercus, which attains $30 \sim 80 \%$ of the arboreal pollen, and by dominance of Pinus, Castanopsis, Alnus, Betula and Carpinus. Gramineae, Artemisia and Chenopodiaceae were predominant in non-arboreal pollen. The pollen diagram was divided into 19 pollen zones, on the basis of pollen assemblages and fluctuation of ratio of arboreal and non-arboreal pollen (Fujii et al. 2004, Maki et al. 2004). According to Fujii et al. (2004) and Maki et al. (2004), a paleoclimatic curve obtained from the Kathmandu Basin sediments well-corresponds to $\delta^{18} \mathrm{O}$ curve ranging from MIS 2 to MIS 19. In addition, paleoclimatic record
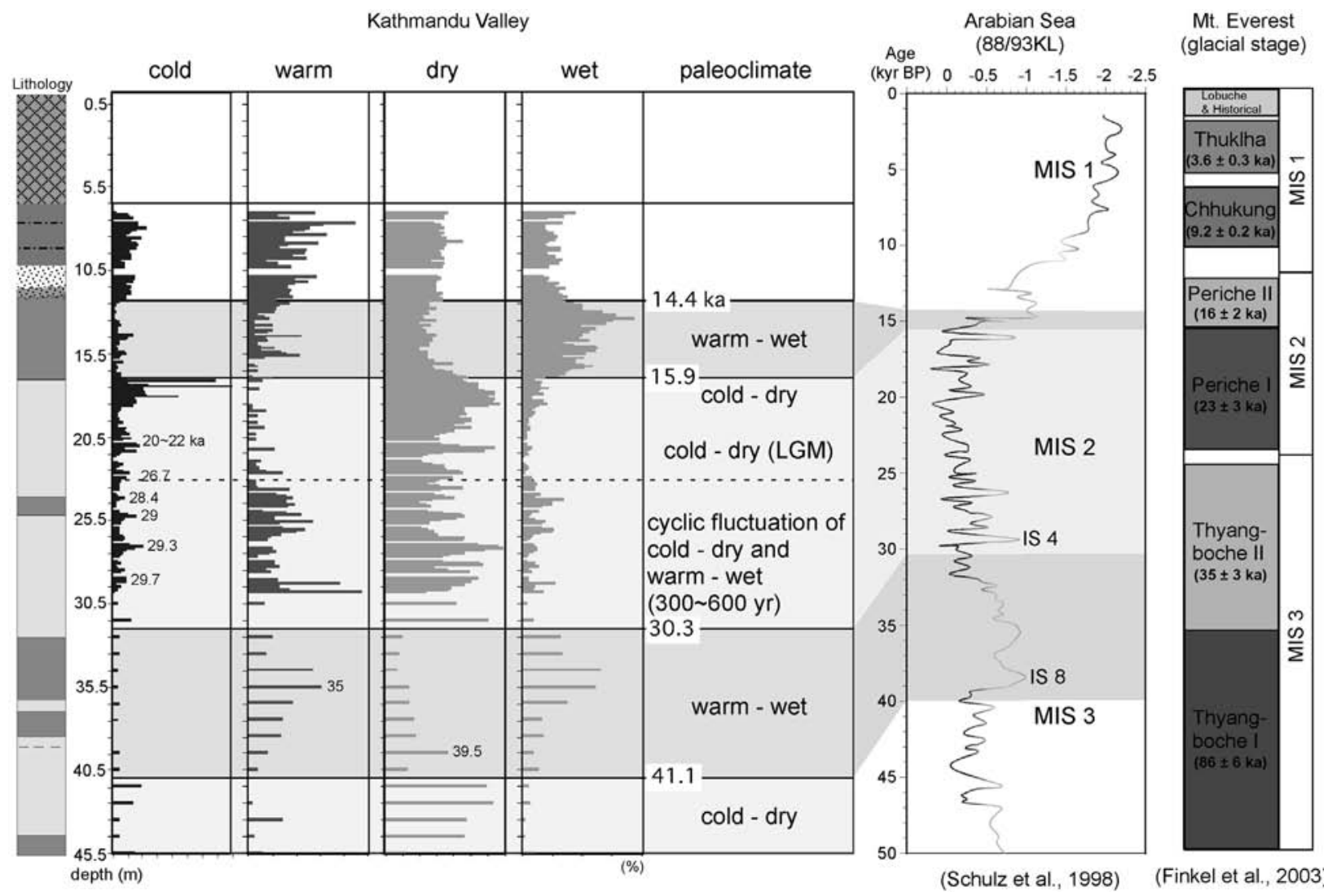

FIGURE 1. Comparison of paleoclimatic records in the Kathmandu Basin with $\boldsymbol{\delta}^{18} 0$ variation curve in the Arabian Sea and timing of expansion of glaciers in the Everest area. Paleoclimatic records are based on assemblage of representative fossil-pollen. 
in the valley is divided into two parts at boundary between MIS 8 (pollen zone 10) and MIS 9 (pollen zone 11), judging from drastic changes of numbers of pollen concentration: the lower part is three to four times larger than the upper part. Moreover, interglacial periods of MIS 11 and MIS 13 were warmer-andwetter climate, in comparison with interglacial periods from MIS 2 to MIS 19. A pollen diagram of the topmost $45 \mathrm{~m}$ in depth range after MIS 4, and is generally characterized by lower number of pollen concentration and low ratio of pollen indicating warmtemperate climate like as Castanopsis and Mallotus.

As a result of pollen analysis at $10 \mathrm{~cm}$ intervals, we could have reconstructed paleocliamtic changes in 100 year intervals from $50 \mathrm{ka}$ to $12 \mathrm{ka}$, and then divide paleoclimatic record in the valley into five stages : 1) before ca. $41 \mathrm{ka}$, it was cold-and-dry climate, 2) from ca. 41 to $30 \mathrm{ka}$, the climate became warm-andwet, especially around ca. $35 \mathrm{ka}$, it was warmest-and-wettest climate, 3) from ca. 30 to $26.7 \mathrm{ka}$, the climate was characterized by fluctuation of cold-dry and warm-wet at 300 600 yr intervals, 4) from ca. 26.7 to $16 \mathrm{ka}$, cold-and-dry climate was prevailed. Especially it was coldest in ca. 20 22 ka, which corresponds to the last glacial maximum, 5) from ca. 16 to $14.4 \mathrm{ka}$, the climate became warm-and-wet gradually.

We compared the climatic records in the KathmanduValley with timing of expansion of glaciers in the Everest area during the last glacial period from ca. 50 to $12 \mathrm{ka}$ (Figure 1). Frinkel et al. (2003) reported that extensive glaciation occurred three times in the Everest area : 1) Thangboche II $(35 \pm 3 \mathrm{ka}), 2)$ Periche I (23 \pm 3

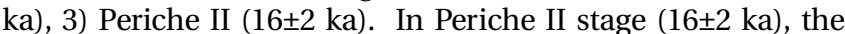
Kathmandu Valley had a cold-and-dry climate, which is characterized by abrupt increase of Pinus and non-arboreal pollen as Gramineae. Periche I ( $23 \pm 3 \mathrm{ka}$ ) corresponds to the last glacial maximum in the Kathmandu Valley, which is characterized by increase of Picea. During the stage of Thangboche II ( $35 \pm 3$ ka), warm-and-wet climate prevailed in Kathmandu. Increase of precipitation under warm climate in Kathmandu around 35 ka suggest strength of the Indian summer monsoon, which must have brought about heavy snow fall in the Everest area and following extensive glaciation.
Method of pollen analysis

Fossil pollen and spores were extracted from the muddy samples by $10 \% \mathrm{KOH}_{-} \mathrm{ZnCl}_{2}$ (s.g. 1.85)-acetolysis method. Microfossils of the treated material were mounted in glycerol on a glass slide. I counted until the two rules where the arboreal pollen (AP) is over 200 grains and the total pollen is over 500 grains for each sample were filled. In the pollen diagram, percentage for each genus of AP was calculated on the basis of the sum of the AP. The percentage for each genus of NAP (non-arboreal pollen: herb pollen and fern spore) was calculated based on the total sum of pollen and spores.

We inferred paleoclimatic changes on the basis of interrelationship between present distribution of vegetation and vertical climatic zonation in the Kathmandu Valley and surrounded mountains. For the purpose of inference of paleoclimate, we used the following genera as climatic indexes: Pinus, Tsuga, Picea and Abies for cold climate, Quercus and Castanopsis for warm climate, Alnus, Betula, Carpinus for wet climate and Gramineae, Artemisia and Chenopodiaceae for dry climate.

\section{References}

Fujii R, T Maki, H Sakai and N Miyoshi. 2004. Paleoclimatic changes during the last ca. $750 \mathrm{kyr}$ recorded in the Kathmandu Valley, central Himalaya. Proceedings of XI International Palynological Congress, Polen.

Maki T, R Fujii, H Umeda, H Sakai, YHase and KShichi. 2004. Paleovegetation and paleoclimate in the Kathmandu Valley and Lake Baikal during the late Quaternary. Proceedings of XI International Palynological Congress, Polen.

Sakai H, R Fujii, Y Kuwahara, BN Upreti and SD Shresta. 2001. Core drilling of the basin-fill sediments in the Kathmandu Valley for paleoclimatic study: preliminaly results. Journal of Nepal Geological Society Special Issue 25: 9-18

Finkel RC, LA Owen, PL Barnard and MW Caffee. 2003. Beryllium-10 dating of Mount Everest moraines indicate a strong monsoon influence and glacial synchroneity throughout the Himalaya. Geology 31 (6): 561-564

Schulz H, UV Rad and H Erlenkeuser. 1998. Correlation between Arabian Sea and and climate oscillations of the past 110,000 years. Nature 393 : $54-57$ 